\title{
Fenomén koronavirové krize v esejích studentů pedagogiky volného času na Teologické fakultě Jihočeské univerzity v Českých Budějovicích Stanislav Suda
}

DOI: $10.32725 /$ cetv.2021.014

\begin{abstract}
Abstrakt:
Téma koronavirové krize je aktuální a prozatím nejsou známa data o způsobech prožívání této krize jednotlivými studenty a o jejich dopadech na studium či profesi. Provedené kvalitativní šetření se proto věnuje prožívání této krize z pohledu studentů a důležitosti jejich postojového ukotvení při zvládání této náročné situace. Studentům bakalářského programu pedagogika volného času byl zadán autorský esej na téma "Já, moje profese a covid“, který byl následně fenomenologicky analyzován za účelem zjištění subjektivní roviny prožívání krize. Ze vzorku 182 esejů bylo odečteno 7 obecnějších postojových kódů, které ilustrují prožívání studentů a způsob vyrovnávání se s tímto fenoménem na základě osobního postoje a ukazují výhodnost určitých postojových kódů (osobního nastavení) pro zvládání dlouhodobé krize. Implikace výsledků je možná ve dvou rovinách: nabízejí metodologickou příležitost ve srovnávacích studiích s očekávanými souběžnými metodicky jinak vystavěnými výzkumy koronavirové krize a taktéž poukazují na nezbytnost aktivního osobního nastavení v dlouhodobé krizi.
\end{abstract}

Klíčová slova: eseje, koronavirová krize, kvalitativní metodologie, postoje, covid-19

\section{Úvodem}

V přemýšlení o zpo̊sobu získávání dat jsme se rozhodli využít potenciál studentů, které doprovázíme studiem $\mathrm{v}$ rámci metodické specializace osobnostně sociální výchovy bakalářského programu pedagogika volného času. Otázka „Já, moje profese a covid“ byla směřována k vlastnímu prožívání fenoménu koronavirové krize. $\mathrm{V}$ upřesňující instrukci bylo zmíněno, že jde o vlastní úvahy v jakékoli formě i délce, nepodléhající žádnému hodnocení. Následně byla tato otázka vyhodnocována fenomenologickou analýzou esejů. ${ }^{1}$ Kvalitativní př́ístup byl poté použit i pro kvantitativní šetření postojů studentů $\mathrm{k}$ této krizi. Podstatu šetření vidíme v pochopení

1 Srov. Tomáš ŘIHÁČEK, Ivo ČERMÁK, Roman HYTYCH a kol., Kvalitativní analýza textů: čtyři př́stupy, Brno: Masarykova univerzita, 2013. 
toho, jaký vztah k nové situaci student zaujme. A jaký myšlenkový proces u jednotlivců probíhá vzhledem k širšímu sociálnímu kontextu z hlediska hodnotového či etického. Z hlediska výzkumného zaměření a nastíněného metodologického a filozofického přístupu bude výhodnější mluvit spíše o smyslu zkoumání než o cílech výzkumu. ${ }^{2}$

\section{K metodologii}

Vzorek se tak skládá ze 182 odevzdaných esejů studentů oboru pedagogika volného času, kteří byli v kontaktu s námi jako s vyučujícími minimálně jeden semestr a měli za sebou odevzdání minimálně dvou a více esejů ve formě otevřených tvarů. Co je tím myšleno? Studenti opakovaně prošli zkušeností s tím, že odevzdaná vlastní autorská úvaha není předmětem hodnocení. Odevzdaný autorský tvar je poskytnut pouze ke zpětné vazbě ze strany ostatních studentů, z pozice vyučujícího je hodnocen jen na škále odevzdal, a tím splnil, či neodevzdal a nesplnil. Což může na jedné straně vést k obsahovému tápání, nicméně na straně druhé tato výpověd jasněji vypovídá o postoji pisatele. Cílem takového shromaždování výzkumných dat je získat svědectví o vnitřním prožívání konkrétních jednotlivých participantů tak, aby výpovědi mohly autenticky zachytit zkoumaný jev. Často to může být svědectví neodborné, naivní, metaforické, s osobním či uměleckým přesahem. Avšak z tohoto partnerského výzkumného pohledu výzkumu „s lidmi“ se jeví jakákoli autentická výpověd’ jako velmi cenná a je nevhodné ji jakkoli hodnotit, s ohledem na budoucí pedagogickou činnost. Participanti by se tak stávali objekty zkoumání „na lidech“, v lepším př́ípadě „o lidech“3.

V současné době je sběr kvantitativních dat v naprosté většině opřen o anonymní sběr dat pomocí elektronických šablon $\mathrm{v}$ internetovém prostředí, na sociálních sítích či adresně pomocí databází studentů a pracovníků. Účelem je nasbírat co největší vzorek respondentů, kteří odpoví na dané otázky. Ve standardní úvaze o způsobu získání kvantifikujících dat bychom se tak zaměřili na předmět výzkumu a stanovili cíle ohledně výzkumného vzorku a výzkumných hypotéz. Z vlastní zkušenosti víme, že vzhledem k četnosti takových dotazníkových šetření postupně klesá motivace respondentů $\mathrm{k}$ účasti na šetření i jejich skutečný zájem věnovat se otázkám a poctivě odpovědět. Domníváme se, že alternativou je vrátit se k osobnějšímu způsobu šetření a vycházet z otázek, které běží hlavou respondentům samotným.

\section{Postoj jako klíč ke zkoumání fenoménu}

Skutečně se domníváme, že výskyt viru a zasažení celé populace prostřednictvím vládních opatření je celospolečenským fenoménem - tedy jevem. Problémem je, že studium a výzkum fenoménů je v současné době upozaděno. Připomeňme tedy metodologické předpoklady. V metodologickém aspektu můžeme vycházet $\mathrm{z}$ předpokladů konstruktivistické teorie, které shrnuje František Jiránek - vztahy reálně existují, jedinec je odkrývá svou činností, tato činnost se vyvíjí z materiální činnosti v činnost myšlenkovou v souvislosti s vývojem abstrakce, tj. schopnosti zaujímat ke světu stanoviska podmíněná stále více sociálně. Pro práci s jazykem to konkrétně znamená, že smysl slova nelze sdělovat tak, že se na designát ukáže. Jedinec se musí k němu dopracovat vlastní činností, spoluprací s druhými, hlavně s dospělými lidmi ${ }^{4}$ V souvislosti se zkoumáním fenoménu

2 Srov. Viktor Emil FRANKL, Viule ke smyslu, Brno: Cesta, 2006.

3 Srov. Vladimír CHRZ, Předmluva aneb Co je vlastně experimentální dramatika, in: Experimentální dramatika, Stanislav SUDA, České Budějovice: Epistéme, 2017, s. 13.

4 Srov. František JIRÁNEK a kol., Otázky psychologie učení, Praha: SPN, 1970, s. 72. 
hry Jiří Černý poukazuje na fakt, že bychom se obecněji neměli soustředit na to, co je fenomén, nýbrž na to, jak s námi tento fenomén je $\mathrm{e}^{5}$. Vzniká tak paradox kvalitativního pohledu na výzkum fenoménů.

Konkrétně v případě krize ohledně koronaviru nejde o výzkum „předmětu“ koronavirové krize. Tedy - co je vir, co je krize, co způsobí, která opatření fungují medicínsky, hygienicky. Optika výzkumu se posunuje směrem k subjektu, který koronavirovou krizi prožívá a podává svědectví. Subjekt je aktivním činitelem $\mathrm{v}$ syntéze nečekaných zážitků vyvolaných současnou situací a ve formulování vlastního postoje $\mathrm{k}$ situaci. Předpokladem výzkumného šetření je tedy objevení určitých postojových kódů v esejích, které vypovídají o tom, jak konkrétní jedinci reagují na tento celospolečenský fenomén. Základní výzkumnou otázku jsme proto dlouho zvažovali a přiklonili se k otevřené možnosti zadání eseje na téma: Já, moje profese a covid. V instrukcích byl opět zdůrazněn esej jako otevřený tvar, možnost téma uchopit jakýmkoli způsobem. Esej nepodléhá žádnému hodnocení textu, splněním je míněno pouze odevzdání textu, který nebude hodnocen ani po stránce obsahové, literární, pravopisné či gramatické. Podstoupit toto riziko se, stejně jako u jiných textů v rámci osobnostně sociální výchovy, opět vyplatilo. A až na naprosté výjimky byly texty v rozsahu jedné až tří normostran.

Jak bylo výše zmíněno, nejdříve bylo potřeba všechny eseje pozorně číst a na kolokviích si kladením dotazů ujasňovat, jak jsou formulace skutečně myšleny. Celý tento proces je vzhledem $\mathrm{k}$ velikosti vzorku oproti klasickému dotazníkovému šetření nesmírně časově náročný. Nicméně se domníváme, že díky užití kvalitativní metody esejů poskytuje autentičtější vhled do problematiky osobního prožívání. Hojně citované pasáže esejů jsou z těchto důvodů delší, abybylo možno ilustrovat způsoby utváření autorské výpovědi - v tom také vidíme klad užití kvalitativní metodologie $^{6}$. Také máme za to, že objevené kódy daleko více vypovídají o vnitřní situaci participantů nežli vyvrácené či potvrzené hypotézy $\mathrm{z}$ odpovědí na otázky zadané výzkumníkem v dotazníkovém šetření.

Ze zmíněného vzorku 182 odevzdaných esejů studentů bakalářského programu pedagogika volného času bylo odečteno 7 obecnějších postojových kódů, které ilustrují prožívání studentů během druhé vlny koronavirové krize.

\section{Prostě to tak je}

Tento typ postoje je definován určitou formálností či nezaujetím. Studenti rozsáhle popisují současný stav, včetně reálií z běžného života. Zajímavé je jakési odcizení a upadnutí do stereotypu. Pokládám si tedy otázku, zda covid ovlivnil i můj život. Vzhledem $k$ tomu, že jsem převážně byla doma, tak mě v podstatě míjel, ale v situacích, $k d y$ si člověk musel dojit např nakoupit nebo jen tak na procházku s dětmi, tak jsem se musela přizpůsobit nařizením, která zrovna momentálně platila. $V$ tom př́padě člověk trochu „bojoval“ s názorem, který na tuto momentálni situaci měl a zároveň se i přizpiosobil. Nebýt mediálního „humbuku“, který se kolem této nemoci strhl, možná bych ani nepoznala, že se něco děje. Ale protože se o tom mluvilo a psalo všude, pak i já jsem postupem času hltala každodenní zprávy a statistiky. Jenže když vám pořád někdo mluví o tom samém několikrát dokola, pak se postupem času stanete imunním. Zvyknete si na to a už je vám to pak spiše na obtíz. Sžijete se s tím a začnete se podle toho i chovat. ${ }^{7}$

\footnotetext{
Srov. Jiří ČERNÝ, Fotbal je hra (pokus o fenomenologii hry), Praha: Československý spisovatel, 1968, s. 11. Srov. Jan HENDL, Kvalitativní výzkum: Základní metody a aplikace, Praha: Portál, 2005.

Ukázka z eseje studentky 1. ročníku bakalářského programu pedagogika volného času, forma distanční.
} 
Studenti tohoto typu postoje se v esejích vyjadřují spíše konvenčně ve smyslu jev tu je a bude, něco dal, něco vzal a tak to je. Nejčastěji se objevuje sdělení, že život jde dál, že snad bude vše jako dřív. Co se týče zkouškového období, doufám, že se vyhneme tomu, aby probíhalo přes Teams. Ale pokud ne, co se dá dělat, budeme to muset zvládnout. Už se těšim až toto období překonáme a vše bude při starém, budeme chodit do školy, do práce, bez strachu budeme navštěvovat své známe, chodit s př́teli na akce a mnoho dalších věcí, na které jsme zvyklí, a chybí nám. ${ }^{8}$

Jak dlouho bude nařizení o zavření škol trvat, se zatím neví. Zabavit děti po delší dobu není snadné, a to jak ty malé, tak ty větší. Ač jsou tato nařizení nepř́iemná a omezující, pokouším se najít i pozitiva. Budeme se s tím muset naučit žít a fungovat jako dř́v. A protože život je jako mozaika složená z malých radostí, užívám si čas s dcerami, vaříme a pečeme manželovi dobroty, učíme se, čteme si, koukáme se společně na filmy. Život jde dál...9

U některých studentů se objevují formální klišé a určité pokusy o jakýsi nadhled a konvenční vtipnost.

Dalším poznatkem dnešní době mưže být nošení roušek před rokem by nikoho nenapadlo, že to dnes bude součástí běžné módy a pokud jí nemáte už jste pro lidi jaksi zvláštní. Je to doba zvláštní, ale hlavní je si v této době zachovat zdravý selský rozum :0. ${ }^{10}$

Jestliže bychom tyto výpovědi interpretovali z hlediska obsahu a formy, pak jednotící kódy dostávat nebudeme. Ona zátěžová situace se promítá do schopnosti konkrétního člověka nějak jí čelit, tedy nějak se k ní stavět. U této skupiny studentů se ukazuje, že se jich situace z různých výše popsaných důvodů téměř netýká, výrazněji nezasahuje do dynamiky jejich osobní angažovanosti.

\section{Frustrace, bezmoc, negace, cynismus}

V další skupině je postojovým kódem již určité emoční zaujetí, které je prožíváno aktivní negativitou. $\mathrm{V}$ tomto ohledu tedy přináší frustraci, aktivně vyjádřený nezájem - otrávenost, touhu po radikálním řešení a zároveň vědomí bezmoci.

Celý tento coronavirus už mě tak štve, že už ani nevím, co k tomu dodat. Zapnu televizi, coronavirus. Otevřu noviny, zase je tu. Zapnu sociální sítě, zase on. Normálně se bojím už jít i do ledničky a na záchod, aby tam na mě nevyskočil, to by byl konec. Reálně by mě zajímalo, co ještě v roce 2020 prijide, mohly by začit padat trakaře z nebe, no ne? Ne počkat, radši pétitisícovky, to by bylo krásně na tom světě. I když vlastně ani tak nebylo, lidi by se pozabijeli. Tak já už opravdu nevím. ${ }^{11}$

$\mathrm{Na}$ základě takto nastaveného emočního naladění je pochopitelné, že by se člověk rád zařadil $\mathrm{k}$ přijetí radikálnějšího postoje vůči druhým. Nicméně dominantní je stále jakási bezmoc. Domnívám se, že tento typ postoje je pro své nositele emočně velmi náročný.

Opatření jako takové mě osobně iritují jako asi každého, ale snažím se je dodržovat, už jen $z$ ohleduplnosti k ostatním. Netvrdím, že je nikdy neporušuji, to asi nemůže tvrdit nikdo, ale dokud to jen jde a dokud jsem mimo okruh svých přátel (o kterých vím, že nemají covid), mezi cizími lidmi, tak je dodržuji. Já přeci nemohu vědèt, jestli ta prodavačka v krámu má nějakýzdravotní problém, ke kterému kdyby se přidal Covid, tak by to pro ni byl rozsudek smrti. Jsem toho názoru, že přísná nařizení, jako zákaz vycházení, či scházení se, vláda musela zavést kvưli té nezodpovědné menšině a doplácí na to všichni. Je to stejný princip jako když ve fabrice, kde se veškerá výroba krásně stíhala i pres to, že si sem tam někdo v pracovní době šel zakouřit nebo na chvíli odpočinout, přijde pár

8 Ukázka z eseje studentky 1. ročníku bakalářského programu pedagogika volného času, forma prezenční.

9 Ukázka z eseje studentky 1. ročníku bakalářského programu pedagogika volného času, forma distanční.

10 Ukázka z eseje studenta 3. ročníku bakalářského programu pedagogika volného času, forma distanční.

11 Ukázka z eseje studentky 1. ročníku bakalářského programu pedagogika volného času, forma prezenční. 
nových lidí, kteři prostě nebudou za celou pracovní dobu dělat vưbec nic. Co může poté vedení dělat? No zavést na tu halu kamery, aby je donutili dělat. Jenže na těchto pár jedinců pak doplatí úplně všichni a $v$ dnešní době už bohužel nejde těm pár jedincưm rozbít ciferník bez riskování mnohem většího trestu, ač si myslím, že to by na né platilo nejvíce. ${ }^{12}$

Velmi výstižně je popsáno vnitřní napětí u studentky, která zvolila za formu výpovědi jakási úsečná komentovaná vyjádření, hesla, otázky, výkř̌iky. $\mathrm{V}$ postojové rovině se projevuje určitý cynismus, jenž je zřejmě obranou před frustrací z neutěšeného emočního naladění a celospolečenské nálady. Ano, opatření možná jsou nutná. Ale dělat z lidi každý týden jiné blázny? Ted' můžete, ted' zase do 21:00 nemůžete? Vidí snad ještě někdo, jak krásně ti nahoře dokážou manipulovat s lidmi? Jak všichni poslouchají a kdo ví, zda to nebude horší? Tohle téma se dá řešit tak dlouho a zároveň mè tak vytáči o tom mluvit. Mluvit o situaci, v kterých jsme. Strašný situaci. Nemůžeš do práce, nemáš penize ..., platit nájem? Nemáš našetřeno - smůla. Chceš alespoň nějaké penize? Vem si půjčku. Ty si nemůžěs vzít ani půjčku? Zkus se zeptat u príbuzných. Ty také už nemají ani na své živobytí? Spáchej třeba sebevraždu... nikdo o tom nemluví, nepiše, nikdo to nevidí ... jsou zaslepeni ... Haha, všude v TV zprávy "všichni si vzájemně pomáhají - Česko šíje rousky". Všichni se spojme a šijme ... Jo... všichni byli v tu chvíli tak úžasní, dobrosrdeční, ochotní. Kde to je ted? Každý den v práci vidím, jak jsou lidi den ode dne zlejší, jsou tak moc sobečtější. Jen sama zlost. Ano, možná to někdo má jinak ... potkává samé pozitivní lidi ... já na to nejspiś štěstí nemám. Lidé si stěžují, urážky chodí zleva zprava. Mužù být milá sebevíc, nepomůže to. Den ode dne horší. Den ode dne si všímám větší a větší zlosti. Další téma ... rouškové pro důchodce? V lehké ironii-> Proč by jsme je měli dávat i samoživitelkám. To zvládnou sami přece. Vždyt mléko a pleny, oblečení pouze na par měsícủ pro miminka jsou za par korun. Vite ... já ani už nevím, jaké rozhodnutí je správné, jaké jsou naopak nesmyslné. Je jich tolik, ze se v tom opravdu člověk rychle ztratí. Tahle doba se mi nelibí. Svět se zbláznil. ${ }^{13}$

V následující ukázce je uveden celý text, kterému dominuje stručnost, zvýrazněné nedodržování pravopisu, přezíravost.

Mě asi nijak zvlášt. Možná mi jen chybí to, že o víkendu nemůžu nikam vyrazit s přáteli a pořádně si tancovat a vypustit všechen stres co se ve mně nahromadí v týdnu nebo si sednout na kávu v týdnu a promluvit si. Tohle mi shází hodně jsem totiž takový kavárenský povaleč. Ale před pár týdny mě něco naštvalo nešlo o mě, ale o mého kamaráda kterého už 3 mèsíce bolí hlava. Byl na testech a je negativní a má $v$ sobě dokonce i protilátky, ale i po všech papirech co doložil doktorce, že je negativní a má protilátky ho stejně jeho doktorka poslala na testy a dál to neřešila, strašně mě to naštvalo. Dyt přece ostatní nemoce nezmizeli jsou tu stále, jsou všude kolem nás. Furt je tu chřipka, angína, neštovice, rakovina a tak dál....To že se o tom nemluví, neznamená, že je to pryč. A koronavirus není středem vesmíru. ${ }^{14}$

Co je této postojové skupině, postojovému kódu nejvlastnější? Z vyjádření je cítit emoční aktivita. Jedinci nenalézají uspokojivé odpovědi na otázky, které krize přináší. Ventilují svoje obavy, frustraci, nespokojenost, vztek.

\section{Úzkost a obavy}

Výpovědi ve spojitosti s úzkostmi a obavami jsou často velmi silné. Základním kódem je určitý defenzivní postoj. Něco se děje, nemáme to pod kontrolou, strachujeme se, jak to celé asi

12 Ukázka z eseje studenta 3. ročníku bakalářského programu pedagogika volného času, forma distanční.

13 Ukázka z eseje studentky 3. ročníku bakalářského programu pedagogika volného času, forma prezenční.

14 Esej plného znění studentky 3. ročníku bakalářského programu pedagogika volného času, forma prezenční. 
dopadne. I když se snažíme zachovat chladnou hlavu, pochybnosti se do mysli dostávají. Vzhledem k chybějící pedagogické praxi i menší životní zkušenosti se mladší studenti s obavami častěji obracejí k sobě a svým problémům ohledně studia. Často se objevují výpovědi o prožívání vlastní neschopnosti organizace času, neschopnosti soustředění, potřeby vnější motivace.

Jak tato pochmurná covidová doba dopadla na mne? Asi největší ztrátu pocituji ve studiu. Jsem člověk, který nemá pevnou vi̊li a už vủbec žádnou trpělivost, což je při studiu $z$ domova docela velké mínus. Samostudium je pro mne trest, nedokáži si sama od sebe ř́ct: „Ted' si jdu nastudovat tohle a tohle...", potřebuji pevný řád a chodit studovat pravidelně do školy. Poslouchat přednášky na živo, ne přes notebook, se kterým můžu sedět, či ležet úplně všude, a to i v posteli. A tak to bohužel dopadá velice často, lehnu si do postele, zapnu přednášku a po chvíli ztratím pozornost. Není to vỉbec nic snadného. ${ }^{15}$

V následující výpovědi studentka popisuje i nejednoduchou situaci v domácnosti a potřebu jakési duševní hygieny či dokonce možností autorských esejů jako terapie.

Covid situace mě už velmi deptá z psychické stránky, jelikož jsem skoro 24 hodin zavřená doma s rejpavým dědou a s mými myšlenkami. Už jsem byla tak na dně ze sebe, že jsem si říkala, že už skončím své studium, protože tolik věcí, co jsem nestíhala dělat mě velmi stresovalo. ... ... Možná by mi pomohlo, kdybych našla nějaké klidné místo, kde by nebyl nikdo a já se mohla vykřičet ze všech mých obav a zamyslet se nad vším, co se mi v posledních několika měsících děje. Nebo ono stačí, když se z toho vypišu, jako ted' tady. Opravdu mi to trochu odlehčilo tu tíhu mých myšlenek. ${ }^{16}$

U starších studentů v kombinované formě se objevuje i starost o vztahy v širším vztahovém rámci. Velmi se tak potvrzuje Jiránkova teze, že vztahy reálně existují, jedinec je odkrývá svou činností, tato činnost se vyvíjí z materiální činnosti v činnost myšlenkovou v souvislosti s vývojem abstrakce, tj. schopnosti zaujímat ke světu stanoviska podmíněná stále více sociálně. V následující ukázce je tento vztahový rámec velmi dobře ilustrován na základě obavy o vychovávané jedince. Je to také ilustrace velmi výrazné pedagogické angažovanosti a zároveň skutečné schopnosti ptát se na širší kontext (ne)smyslu pedagogické práce.

Shrnu-li to: nadháním, sháním, odpovídám na dotazy dětí i rodičù, připravuji se výuku, počítám príklady z matematiky, fyziky, vybarvuji slepou mapu, doučuji. U dětí, které v osmém ročníku neuměji správně napsat českou větu, natož ji vymyslet. U dětí se speciálními vzdělávacími potřebami, či na hraně mentální retardace. U dětí, které jsou podporovány svými rodiči $v$ tom, že nic nemusí. Je to spousta velmi těžké práce s mizerným efektem i za „normálních okolností. V době Covidové si kladu otázku, jak dlouho ještě se to dá přežit. Jednou z úloh asistenta pedagoga je podporovat a rozšiřovat sociální dovednosti u svého svěrence. Distanční výuka nám zrovna tuhle úlohu totálně rozbila. Mám strach, že až se do školy vrátíme, „moje“ děti budou v mnohem horším stavu, než $k d y z ̌$ jsem $k$ nim před třemi lety př̀išla. Viděla jsem je růst, vím přesně, co dokážou, jací jsou. Mám každého z nich ráda. Za těch pár let jsme se sžili a už víme, co od sebe navzájem mưžeme čekat. Ted’ ale vưbec nevím, $k$ jakým dètem se vrátím. ${ }^{17}$

Další ukázka je z eseje, který evidentně zafungoval jako autoterapie. Domnívám se, že je to nejen metodologická, ale zejména etická výzva. Studentka uvěřila, že se může svěřit, podělit se o trápení. Ví, že odpovědi nespadnou do „mašiny“, která je objektivně vyhodnotí. Dostane na svoji výpověd’ zpětnou vazbu a hledá autentické vyjádření. K tak hlubokým sdělením se pomocí kvantitativní metodologie dobrat nemůžeme.

15 Ukázka z eseje studentky 1. ročníku bakalářského programu pedagogika volného času, forma prezenční.

16 Ukázka z eseje studentky 1. ročníku bakalářského programu pedagogika volného času, forma prezenční.

17 Ukázka z eseje studentky 2. ročníku bakalářského programu pedagogika volného času, forma distanční. 
Ted’ premýšlím, jestli sem mám zahrnout i tu největší ránu, který mě za tohle období nejvíc postihla. $V$ květnu nás opustila moje babička, byla nemocná, ale že to bude takhle brzo, nad tím jsme nikdo $z$ nás nechtěl ani pomyslet. Posledních pár týdnů před už to ale začínalo být opravdu vážné a víte co bylo na tomhle všem nejhorší? Že vzhledem ke koroně jsem se s ní nemohla ani rozloučit. Není den, kdy bych neproklínala tuhle špatnou dobu a nevyčítala si, že i když to bylo takhle na nic, že jsem se nevykašlala na veškerá opatření a prostě za ní nešla a nerozloučila se. At’je to, jak chce, na tenhle rok nikdo z nás asi nikdy nezapomene. Nebýt mojí rodiny, se kterou jsem ted'každý den, tak nevím, jak bych tohle všechny psychicky zvládla. Ale i tak se modlím, aby tohle všechno už skončilo a bylo zase všechno jako dř́v a $v$ pořádku. ${ }^{18}$

Jestliže bychom se pokoušeli tyto výpovědi interpretovat $z$ hlediska obsahu a formy, pak jednotící kódy opět dostávat nebudeme. $V$ tomto př́padě však ona zátěžová situace velmi výrazně zasahuje do osobnostních struktur. Jedinci cítí velmi silný tlak a určitou odpovědnost za dopady situace na sebe, někdy i ostatní. Nicméně jsou ve vyjadřování postoje skutečně v defenzívě, dokonce určité bezmoci. A to zvyšuje jejich pocit obav a strachu.

\section{Zastavení, výzva}

Aby byla dobře ilustrována tato postojová skupina, uvedu př́klad, který obsahově koresponduje s ukázkou eseje v předchozí kapitole. Autorka se taktéž potýká se ztrátou milované osoby, dokonce vlastního dítěte. Nicméně nachází vysvobození v konkrétní činnosti - smysluplné práci. Tato aktivita ji vyvádí $\mathrm{z}$ beznaděje, a tím se její postoj mění.

... odešel navždy můj syn a já se propadla do zármutku a se mnou truchlila i celá zem ... Zachránila mě, doslova, moje práce a moje škola. To, že jsem mohla každý den, alespoň na malou chvilku, dělat tak záslužnou a v té dobè smysluplnou práci, bylo jako balzám na bolavou duši. Šila jsem roušky, ano opravdu, naše škola se promènila v jednu bezvadně fungujicí a spolupracujicí manufakturu, na něco, co nám všem mohlo zachránit život. A tak jsme hledali látky, stř́hali a žehlili, a nakonec ušili tak krásné roušky, které náš pan ředitel vozil všem, kteři je potřebovali ... Jak tedy epidemie změnila a ovlivnila mojí profesi a můj život? Myslím, že mi vzala pocit svobodně se pohybovat, ale také jsem dostala něco na oplátku. Dostala jsem čas, čas $k$ zastavení, čas $k$ zamyšlení a v neposlední radě čas $k$ uvědomèní si svého vlastního já. ${ }^{19}$

Následující ukázka z eseje ukazuje, jak studentka aktivně, cíleně a vědomě svůj postoj mění. Nebere situaci pasivně, necítí se sociálně determinována. Uvědomuje si, že velký prostor pro změnu pohledu je v jejím vlastním přístupu. V tomto ohledu se asi pokouší uvést v život Franklovu tezi, že sociální okolnosti nezměníme, ale mưžeme změnit svůj vztah $\mathrm{k}$ nim. ${ }^{20}$ Velmi zajímavé je také zaznamenání určitého vnitřního dialogu, který postojové změně pomáhá.

Pưvodně jsem měla $v$ plánu se tu hodně rozepsat o tom, jak trpím, poplakat si tu. Ale myslím, že každýz nás bojuje vnitřně sám se sebou. Aby se sebou vůbec vydržel. Každý máme nějaký starosti, nějaký depky. A je to $v$ téhle době v pořádku. Proto bych možná konec chtěla vzít úplně z jiného pohledu. Děkuju za to, že jsme ještě pořád zdraví. A nikoho se covid v rodině až moc nedotkl. Děkuju $z a$ to, že můžu s rodinou trávit víc času, protože bychom jinak neměli čas si udělat kávu, sednout si společně ke stolu, hrát dobbla nebo si jen čist knižku. Děkuju za to, že mám prítele, se kterým můžu trávit čas. Protože i když je hezký trávit čas s rodinou, každýz nás zná slovo ponorka. ${ }^{21}$

18 Ukázka z eseje studentky 1. ročníku bakalářského programu pedagogika volného času, forma distanční.

19 Ukázka z eseje studentky 1. ročníku bakalářského programu pedagogika volného času, forma distanční.

20 Srov. Frankl, Vuile...., s. 109.

21 Ukázka z eseje studentky 3. ročníku bakalářského programu pedagogika volného času, forma prezenční. 
Jestliže bychom měli nějakým způsobem popsat rozdíl v postojích mezi první (formálnější) postojovou skupinou a touto třetí skupinou, pak je to vyznění posledních řádku ukázky. Autor vyjadřuje určitou naději ve změnu k odpovědnějšímu chování lidí. Má za to, že covid je určitou výzvou $\mathrm{k}$ této změně a chce tuto výzvu přijmout.

Ekonomové vyčíslují dluh státu a obrovské finanční dopady a vlastně celá společnost sčitá ztráty. Těšim se, až svou pedagogickou profesi budu moci zas plnohodnotně vykonávat, otázkou je, za jakých podmínek. Myslím, že Korona virus zůstane součástí společnosti, která se bude muset prizpưsobit a žit po jeho boku. Mnoho lidí si to již uvědomilo, někteři však bohužel přestali hledět doleva či doprava, mírí vpred stejně, jako v době před tím, než se Covid 19 zapsal do slovníků a zapomínají na toto poselství prírody k lidstvu. Já se ale nechci vrátit do starých kolejí, máme nové výzvy, přiležitosti, které mohou být kořením našeho života i profese. ${ }^{22}$

Obsahově se tyto výpovědi týkají i studijních výzev. Přes vnitřní nejistotu a pochyby však převažuje onen aktivní postoj.

Někdy si říkám, že v každodenním shonu, stresu, napětí, kdy se na mě/nás valí spousta učiva, bych nejraději před tím někam utekla a říkám si „,Proč? Mám to zapotřebí?" Ale pak se zastavím a utvrdím se, že smysl to má. Vždyt’ vzdělání je $v$ dnešní době tolik potřebné a myšlenka, že mi napomůže k mé vysněné práci, určitě smysl má a velký. A mimo jiné, má to i své světlé chvilky, vždyt’studium umožňuje se setkávat, poznávat nové lidi, kteří, jak znám, můžou být dobří partáci do života. $Z$ mého pohledu, každý člověk by mèl mít sny, nebo cíle, kterých by chtěl dosáhnout a vědět, kam $v$ životě směrovat a takový má být smysl života. Takže můj cíl je zdárně a s úspěchem studovat ... ${ }^{23}$ Objevují se také výpovědi studentů, kteři již nemocí prošli a nějak museli reagovat. V této ukázce je nastíněna změna postoje díky zvládnuté nemoci. Autor popisuje jakési uvolnění, lepší naladění, a přestože k nemoci respekt má, defenzivní postoj povolil.

Po překonání nemoci jsem celkově uvolněnější a lépe naladěný, než když jsem se bál, že nemoc dostanu a nevěděl jsem, jaký to může mít prüběh. Takže nemoc respektuji, dodržuji všechna nařizení, nestýkám se se svými rodiči, prarodiči ani nikým jiným z rodiny, ale zase na druhou stranu se již tolik nepoddávám tomu strachu, jako na začátku... a zprávy pořád nečtu ani nesleduji v televizi... ${ }^{24}$

\section{Provokace k výkonu}

Původně se zdálo, že následující postojový kód mohl být ryze specifický díky vykonávané profesi. Nicméně poté převážila úvaha, že je to možná naopak. Určitá profese přitahuje lidi s určitým postojem ke světu. Přestože do této postojové skupiny spadají pouze tři výpovědi, je dobré o tomto výkonovém postoji hovořit jako o obecnějším. Vedle vojáka a policisty je zastoupena i policistka. Co se postojového vyjádření týče, jsou tito lidé nečekanou situací velmi motivováni, objevují novou energii. Uvědomují si štěstí, že mají profesi, ve které se nacházejí profesně i lidsky, a že mohou skutečně pomáhat.

V první ukázce se jedná o postoj, který je krizí v podstatě jen akcelerován. Student si je vědom hodnoty, kterou mu práce v armádě přináší. Dokonce se odkazuje na již odevzdané eseje a dalšími úvahami jen zpřesňuje svoji až vášnivou představu o možnostech dalšího vzdělávání. A také odkazuje k širšímu sociálně podmíněnému jednání z hlediska své funkce.

22 Ukázka z eseje studenta 2. ročníku bakalářského programu pedagogika volného času, forma distanční.

23 Ukázka z eseje studentky 1. ročníku bakalářského programu pedagogika volného času, forma distanční

24 Ukázka z eseje studenta 3. ročníku bakalářského programu pedagogika volného času, forma distanční. 
Moje profese je v současné době poměrně specifická. Když to vezmu obrazně, v mé práci cvičime, válčíme, nebo čekáme na nějakou pohromu ... ... Během této práce si vlastně člověk uvědomuje, co studuje. Díky tomuto studiu se začínám pomaličku, ale jistě dostávat do dané problematiky. Zjistil jsem, že práce v ozbrojené složce, konkrétně v armádě, je úzce spojena s pedagogikou a psychologií. Vzhledem $k$ tomu, že jsem už pár let ve velitelském sboru, tak musím souhlasit s tím, jak se ríká „dobrý velitelem je pedagog a psycholog zároveñ “.. V první eseji jsem psal, že po vystudování bych chtěl navázat na dalši studium, abych mohl později vzdělávat děti ve sportu na základní škole. Nejspiš přehodnotím trochu své uvažování, protože bych chtěl nejspiš vzdělávat velitelský sbor v AČR. Pravděpodobně sám sobě dávám velký úkol, jelikož v armádě nikdo doposud nepřišel s myšlenkou, aby se vzdělával nejnižši velitelský sbor. Tito velitelé totiž nemají žádné pedagogické vzdělání a někteři nejsou ani empatičtí. Což je někdy velmi nepř́íemné. Paradoxně jejich hlavním úkolem je učit své podřizené novým dovednostem a préedávat dál své zkušenosti. Bez těchto základi̊ to nemohou nikdy provádět správně. Tímto bych shrnul své uvažování. Nyní je to lehce náročné, skloubit všechny aspekty dohromady, práce (pomoc obyvatelstvu ČR), rodina a studium. Jen tak to ale nevzdám, protože kolektiv profesorů a spolužáků je výborný. Zároveň má motivace a myšlenka k rozvíjení velitelského sboru, jako úspěšných pedagogů, mě žene kupredu... ${ }^{25}$

Pro ilustraci tohoto postoje je velmi vypovídající esej, možná spiš sebereflexe ženy, která slouží u policie. $V$ dobrém ukazuje hodnotu toho, když se člověk nalézá v konkrétní práci, která je potřebná, pomáhající, stává se skutečným posláním.

Pracuji jako policistka České republiky na obvodním oddělení. V současné době jsme rozdělení na skupiny A a B, abychom se navzájem nepotkávali. Jsme malé oddělení a v současné době je nás 11 policistů. Naše oddělení je opravdu velmi malé, ř́káme tomu „oddělení rodinného typu. “Přesto, že se snažíme všichni nosit roušky, vše řádně desinfikovat, i tak nás Covid zasáhl. Už v takto malém počtu dáváme horko těžko dohromady služby a do toho ted' Covid. Protože je nás opravdu velmi málo, máme velký podstav lidí, mnohdy sloužíme i nad rámec pracovní doby. Tyto hodiny se nám nikam nepočitají. Sloužíme 12, 24 i 35 hodin služby. Někdy je to opravdu velmi náročné. Jsem ráda, že i presto jaká panuje vůči Covidu atmosféra, se snažíme všichni si pomáhat ... Někteří přehodnotili svůj život a začali žit jinak. Tak nějak lépe, v klidu. Najednou mají čas na jakousi revizi svého života. Někteři nepocitují žádnou změnu a těši se na vrácení se do „starých kolejí. “ A jde to vůbec? Až toto pomine bude život jako dřiv? A pomine to někdy? At už je to jakkoli, doufám, že je to jako v tomto citátu: „V̌̌echno zlé, je pro něco dobré" a príjde jakýsi restart do nového začátku. Před a po Covidu. Přeji štastnou a láskyplnou cestu všem. Já jsem si díky této zkušenosti uvědomila, že jsem za svou práci vděčná. I když je to někdy opravdu velmi náročně a stresující, obzvlášt pro ženu, a někdy bych chtěla dělat něco úplně jiného, jsem ráda, že práci mám a do budoucna se všechno uvidí. Chci dělat takovou práci, pro kterou jsem se narodila. Nyní jsem a mohu být užitečná. Myslím, že je mým posláním pomáhat lidem. ${ }^{26}$

Tato výpověd otevírá prostor pro eseje, které mají skutečně hlubší, řekněme, etický rozměr.

\section{Hluboké přijímající eseje}

V následujícím eseji je vyjádřeno něco, co by se dalo nazvat určitým uměním porozumět si. Studentka aktivně pracuje na tom, aby její porozumění ve zpětné vazbě ke klientce i sobě samé nabíralo směr k hledání smyslu činění a sebepřijetí.

25 Ukázka $\mathrm{z}$ eseje studenta 1. ročníku bakalářského programu pedagogika volného času, forma distanční.

26 Ukázka $\mathrm{z}$ eseje studentky 2. ročníku bakalářského programu pedagogika volného času, forma distanční. 
Přesto, že se svět stále točí kolem covidu, tak náš svět je plnýjiných starostí, se kterými musíme bojovat. Není to jednoduchá situace, ale mám v rodině bojovníky, kteří nad těmi zdravotními problémy musí vyhrát. Pevně věrím, že zvítězí. Jedno malé vítězství se stalo v mé profesní stránce. Díky komplikacím ohledně praxí se naskytla možnost pracovat individuálně s paní na vozíku, která má spinální muskulární atrofii. Není to občas jednoduchá praxe, ale nějak vnitřně mě tato práce velmi naplňuje. Možná je to tím, jak krásně dokáže klientka vyjádřit vděk a radost. Nikdy by mě nenapadlo, že se $v$ takové práci opravdu najdu. Dostávám velký obdiv, hlavně od blizkých, kteří oceňují, že jsem do takové praxe šla. Vím, že mě to posunulo zase o malý krưček výš na mé profesní dráze ... ... I na mé dráze studentským životem se to poznamenalo, zejména při psaní autorských textů. Troufnu si říct, že si toho všiml snad každý při našem oblíbeném předčítání. V posledních rýmovačkách jsem lehce naznačovala bolesti, které jsou v mém životě aktuální. Pokaždé jsem musela pro svi̊j osobní klid trochu odlehčit. Odlehčuji nejen pro ostatní, kteří mají svých starostí dost, ale hlavně pro sebe. Při praxi jsem si totiž uvědomila, že v našem uspěchaném světě, řešíme spoustu banalit. Moje klientka mi otevřela oči. Řeší věci s větším nadhledem než běžný člověk, prestože prožívá trápení den co den. ${ }^{27}$ Poměrně paradoxní účinek má v následném textu zkušenost s psychickou nemocí. Autor tuto zkušenost vnímá jako kladnou, jako něco, co ho připravilo na dnešní situaci. V textu také dominuje zájem o psychoterapeutický pohled.

Pandemie korona viru zajisté přinesla mnoho změn. A také príležitost zamyslet se sami nad sebou. Jakým způsobem života žiji, jaké vyznávám hodnoty. Každý by si měl položit otázku: Isem štastný? Najednou máme více času. Můžeme reflektovat sami sebe, možnost to brát jako očistnou katarzi k vlastní sebereflexi. "Mnoho lidí nesnáší neděli, protože mají čas přemýšlet, jakým způsobem života žiji”, říká psychoterapeut Dalibor Špok. Je to zkouška mezilidských vztahů. Kvưli současným opatřením jsou lidé nuceni trávit více času doma. A pokud není soužití ideální, mũže to situaci ještě zhoršit, protože není tolik možností úniku. Dalším důsledkem je tzv. home office, který se často používá, tedy práce $z$ domova. Hodně se mluví o moderních technologiích, které pomáhají nahrazovat osobní kontakt, který nyní chybí. At’už jako home office, v rámci distanční výuky nebo jen tak si zavolat. Jak uvádí Dalibor Špok, i pro něj je psychoterapie na dálku nová zkušenost. Souhlasím s ním, že hodně lidí nedokáže být sama se sebou. Bojí se přiznat problém, tuší, že je něco špatně a že by to měli zmènit. K tomu je totiž třeba úsilí a obět', trpělivost a čas. Říká se, že krize je šance na změnu. Snad mám dar na všem špatném vidět něco dobrého a to si vzít. Každopádně současná situace donutí každého si uvědomit, že nic není samozřejmost. Že je třeba vážit si zdánlivě obyčejných věcí, jako třeba možnost posedèt s někým u kávy. Mám štěstí, že jsem našel práci, která je určena těm, kteři by jinak neměli šanci. Díky tomu vím, co je to home office. A dnes tato skutečnost nabývá na významu. Lidé více prožívají úzkosti, deprese a osamèlost. Tedy podobně jako ti s psychickými problémy. Jelikož tohle znám řadu let, jsem na to připravený. Vím, co mohu čekat a co mám dělat. Nepřekvapí mne to. Tak toto jsou tedy pozitiva, alespoň pro mne $v$ době, kterou právě prožíváme ... ${ }^{28}$

\section{Distanc}

Celkem 7 esejů se svým postojovým sdělením nějakým způsobem vymykalo možnosti zařadit je mezi obecnější kódy. Bud’ jsou neovlivněni jakoukoli emocí nebo problém popírají. Někteří úkol pouze splnili. Svým postojem se distancují od problému, od zadání, od společenského dění.

27 Ukázka z eseje studentky 3. ročníku bakalářského programu pedagogika volného času, forma prezenční.

28 Ukázka z eseje studenta 1. ročníku bakalářského programu pedagogika volného času, forma distanční. 
Můj názor je, že je to jedna velká celosvětová fraška a naše vláda tomu dává korunu. ${ }^{29}$

\section{Souhrn dat}

Jak bylo na začátku studie anoncováno, základní výzkumnou otázkou bylo zjištování, jaký myšlenkový proces u jednotlivců probíhá vzhledem $\mathrm{k}$ širšímu sociálnímu kontextu $\mathrm{z}$ hlediska hodnotového či etického a jaký vztah k nové situaci studenti postojově zaujímají. Na základě této úvahy a kvalitativní analýzy odevzdaných prací lze usoudit, že studenti zaujímají ke koronavirové krizi 7 výše popsaných postojových úhlů (kódů). Z hlediska kvantitativních poměrů se výpovědi o celkovém počtu 182 esejů rozložily takto:

1. V postojovém kódu „Prostě to tak je“ vypovídalo 63 respondentů, tj. $35 \%$.

2. V postojovém kódu „Frustrace, bezmoc, negace“ vypovídalo 15 respondentů, tj. $8 \%$.

3. V postojovém kódu „Úzkost a obavy“ vypovídalo 41 respondentů, tj. $22 \%$.

4. V postojovém kódu „Zastavení, výzva“ vypovídalo 37 respondentů, tj. $20 \%$.

5. V postojovém kódu „Provokace $\mathrm{k}$ výkonu“ vypovídali 3 respondenti, tj. $2 \%$.

6. V postojovém kódu „Hluboké přijímající eseje“ vypovídalo 16 respondentů, tj. $9 \%$.

7. V postojovém kódu „Distanc“ vypovídalo 7 respondentů, tj. $4 \%$.

\section{Diskuze a závěr}

Použití kvalitativní metodologie podává autentičtější zprávu o postojích konkrétních studentů. Výsledné schéma je vytvořeno tzv. zdola - jednotlivé postojové kategorie vystupovaly z textů samy na základě interpretace jevu koronavirové krize. ${ }^{30}$ Respondenti se nemusí zařazovat a přizpůsobovat do kategorií připravených výzkumníkem ve struktuře dotazníku. Sami - de facto - kategorizaci svými výpovědmi vytvořili. Výzkum tak $\mathrm{z}$ hlediska participace nastiňuje etičtější pohled na participanta jako partnera. Inklinuje k výzkumu „s lidmi“ spíše než k výzkumu „o lidech“, kde jde primárně o získání dat. Vzhledem $\mathrm{k}$ tomu, že první srovnatelná data budou teprve přicházet v době vydání tohoto čísla časopisu, jsme zvědavi, zda kolegové výzkumníci počítali při sběru dat s postojovými kódy participantů výzkumu. $\mathrm{V}$ tomto ohledu se otevírá prostor pro budoucí srovnávací studie a metodologické posouzení jednotlivých postupů.

Z pohledu samotného rozložení postojových kódů ve zkoumaném vzorku studentů bakalářského programu pedagogika volného času můžeme vycházet $\mathrm{z}$ jakýchsi třech směřování osobnostní dynamiky. V kódech 1 a 7 se jedná o nevyhraněný či formální postoj, v kódech 2 a 3 jde o určité stupně defenzivního postoje od obav $\mathrm{k}$ frustraci, kódy 4,5 a 6 poukazují k určité škále vlastního aktivního př́stupu $\mathrm{k}$ problematické situaci od zastavení se $\mathrm{v}$ čase $\mathrm{k}$ aktivitě či hlubším úvahám na základě neočekávané situace. $\mathrm{V}$ tomto ohledu je přibližné procentuální rozložení těchto skupin cca $40: 30$ : 30. Prvotní myšlenka vede $\mathrm{k}$ tomu, že $40 \%$ postojově nevyhraněných a formálně uvažujících studentů ve studiu pomáhající profese je poměrně vysoké č́slo. Na druhou stranu zbývá 60 \% studentů, kteří nějakým způsobem výrazněji reflektují svůj postoj, at už defenzívně či aktivně. Tato čísla mohou být dobrými vstupními daty nejen $\mathrm{k}$ diskuzím o společenském dopadu koronavirové krize, ale také mohou pomoci definovat žádoucí osobnostní a postojové nastavení studentů a pracovníků v pomáhajících profesích.

29 Ukázka z eseje studentky 1. ročníku bakalářského programu pedagogika volného času, forma distanční.

30 Srov. Řiháček, Kvalitativní... 
caritas

elveritas

\section{Kontakt}

doc. MgA. Stanislav Suda, Ph.D.

Jihočeská univerzita v Českých Budějovicích

Teologická fakulta

Katedra pedagogiky

Kněžská 8, 37001 České Budějovice

suda@tf.jcu.cz 